\title{
Geology of the Pontinvrea area (Ligurian Alps, Italy): structural setting of the contact between Montenotte and Voltri units
}

Laura Federico, Laura Crispini, Cristina Malatesta, Silvia Torchio \& Giovanni Capponi

To cite this article: Laura Federico, Laura Crispini, Cristina Malatesta, Silvia Torchio \& Giovanni Capponi (2015) Geology of the Pontinvrea area (Ligurian Alps, Italy): structural setting of the contact between Montenotte and Voltri units, Journal of Maps, 11:1, 101-113, DOI: 10.1080/17445647.2014.945749

To link to this article: https://doi.org/10.1080/17445647.2014.945749

( 2014 Laura Federico

Published online: 07 Aug 2014.

山 Article views: 685

View Crossmark data ד
+ View supplementary material ๘

Submit your article to this journal 주

Citing articles: 2 View citing articles ๔ 


\title{
SCIENCE
}

\section{Geology of the Pontinvrea area (Ligurian Alps, Italy): structural setting of the contact between Montenotte and Voltri units}

\author{
Laura Federico*, Laura Crispini, Cristina Malatesta, Silvia Torchio and Giovanni Capponi \\ DISTAV, University of Genova, Genova, Italy
}

(Received 30 January 2014; resubmitted 29 May 2014; accepted 21 June 2014)

\begin{abstract}
This geological map at the 1:10,000 scale shows the structural setting of two poly-deformed metaophiolite units, with different metamorphic peak conditions, i.e. the blueschist facies Montenotte Unit and the eclogite facies Voltri Unit, in a selected area of $8.2 \mathrm{~km}^{2}$ within the Ligurian Alps (northern Italy). This study focuses on the tectonic contact between the two tectono-metamorphic units and on their relationships with the Oligocene sediments of the Tertiary Piedmont Basin. The map is a composite report of our field and laboratory study of structures and metamorphism, that explains our interpretation of the tectonic history of the study area. It shows that the two units were coupled during their exhumation path, along a blueschist facies mylonitic contact. This contact has been later involved in thrust faults that caused the superposition of the metamorphic basement on top of the Oligocene sediments.
\end{abstract}

Keywords: HP metaophiolite; structural mapping; Montenotte Unit; Voltri Unit; Ligurian Alps

\section{Introduction}

This geological map (Main Map) is the result of a detailed analysis of an area chosen for its peculiar structural features, in the eastern Ligurian Alps (Figure 1a). In this area (Figure 1b) two tectono-metamorphic units with different peak metamorphic re-equilibration crop out, i.e. the blueschist facies Montenotte Unit and the eclogite facies Voltri Unit.

Our map covers an area of $8.2 \mathrm{~km}^{2}$ and falls inside the Savona province, NE of the Pontinvrea village, in the Ligurian inland area (NW Italy). This area represents the eastern part of the Ligurian Alps, i.e. the southern termination of the Western Alps (Figure 1a). Both the Montenotte and the Voltri units are Ligurian-Piemontese metaophiolitic units, belonging to the Penninic domain of the Western Alps; they underwent a complex structural and metamorphic evolution during subduction and exhumation in the alpine orogenic cycle (Laubscher, 1971; Malatesta, Crispini, Federico, Capponi, \& Scambelluri, 2012; Polino, Dal Piaz, \& Gosso, 1990). The Montenotte and Voltri units are overlain by the Oligocene clastic sediments of the Tertiary Piedmont Basin (TPB), that is a syn-tectonic Neoalpine-Apennine Basin, which evolved in a piggy-back position on the Monferrato thrust belt (Gelati \& Gnaccolini, 1988, 1998; Lorenz, 1968; Mutti et al., 1995).

In the mapped area (Figure 1b), the Montenotte and the Voltri units were deformed and metamorphosed at different PT peak conditions but at present they are involved in a common structural

\footnotetext{
${ }^{*}$ Corresponding author. Email: federico@dipteris.unige.it
}

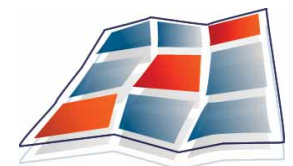




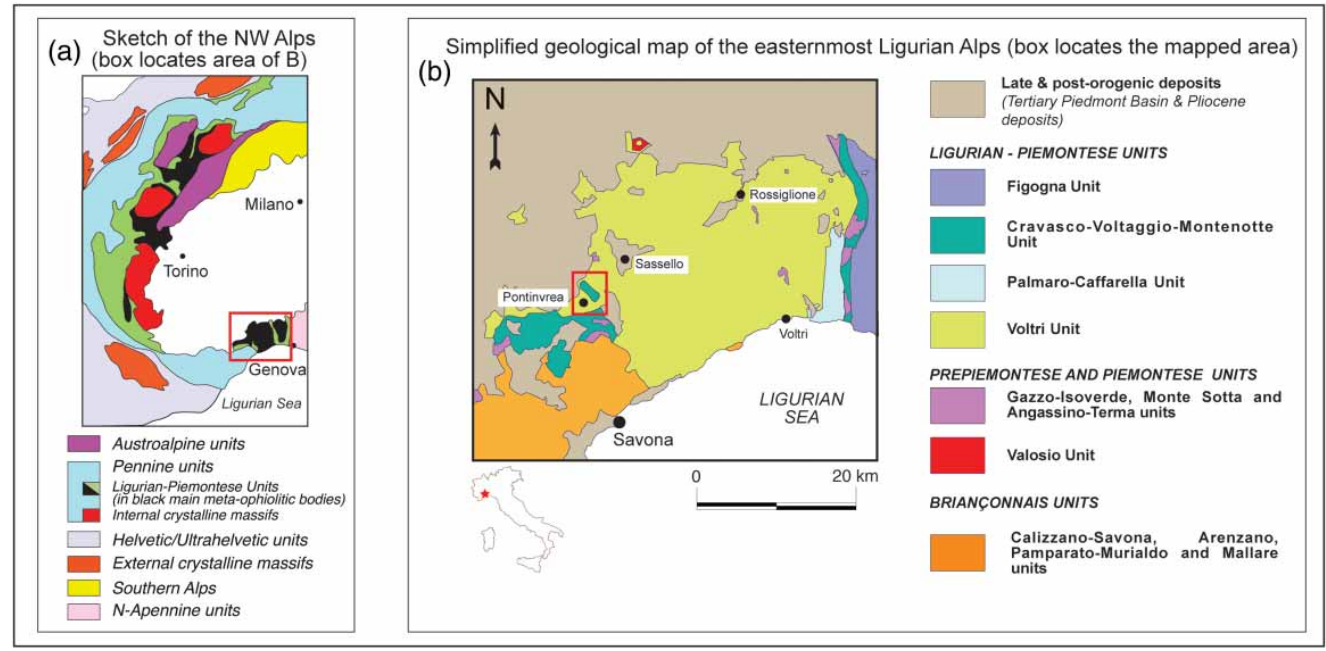

Figure 1. a: Tectonic sketch of the Western Alps; b: Schematic geological map of the eastern Ligurian Alps with the study area.

architecture. We did this study in order to decipher and reconstruct the tectonic history that characterizes the coupling of the two units. It's important to outline that very few studies on the Montenotte Unit (Anfossi, Colella, \& Messiga, 1984; Beccaluva, Macciotta, Messiga, \& Piccardo, 1979; Messiga \& Piccardo, 1980) have been published so far and this was one additional reason of our choice of the area. Our analysis regards also the relationships between the metamorphic basement and the overlying sediments of the TPB.

This geological map (Main Map) is a combined report of our field and analytical laboratory work performed to reconstruct the relationships between the deformation stages, the metamorphic evolution and the lithostratigraphy. The geological map is accompanied by two cross-sections and a structural sketch map, that explain our interpretation of the geological architecture of the study area, derived from the analysis of the structures and the metamorphism related to the different deformational events.

The aim of this work is (1) to provide an update of the geology of the area, (2) to study the structural relationships between the Montenotte and Voltri units, (3) to study the mode of emplacement and coupling of the two units during exhumation, and (4) to study the relationships between the metamorphic basement and the clastic sediments of the TPB.

\section{Methods}

The base of data for this work comes from a field mapping at 1:10,000 scale, in the framework of a larger project funded by the Regione Liguria, which covers the Ligurian part of the 212 'Spigno Monferrato' quadrangle. This project was intended to update the geological maps available for this area, i.e. the 'Ceva' quadrangle (Francani et al., 1971) and small part of the 'Genova' quadrangle (Allasinaz et al., 1971) at 1:100,000 scale. As topographic base during the field work, we used the 1:10,000 scale 'Carta Tecnica Regionale' of the Regione Liguria.

Because of its structural complexity, this area required a dedicated analysis that involved the detection of several deformational events, the understanding of their mutual overprinting relationships and the correct attribution of the collected structural data to the relative deformational stage. Using the words 'tectono-metamorphic unit' we mean a rock volume that can be distinguished 
from the adjoining rocks on the base of the metamorphic features and/or of the internal structural features and/or of the structural position with respect to other units (e.g. Spalla, Zucali, Di Paola, \& Gosso, 2005).

\section{Geological setting}

\subsection{The Montenotte unit}

The Montenotte Unit crops out at the eastern part of the Ligurian Alps, W-SW of the Voltri Unit (Figure 1b); it encompasses an ophiolitic succession metamorphosed under blueschist facies condition, and made up of serpentinite, predominant metagabbro (both Fe- and Ti-oxyde-rich and Mg-rich facies), metabasalt, metachert, meta-limestone and phylladic schist. The mineralogical assemblage includes albite + chlorite + Na-amphibole \pm Na-pyroxene \pm lawsonite \pm pumpellyite \pm epidote in metagabbro (Cabella, Cortesogno Gaggero, \& Lucchetti, 1994; Capponi, Crispini, \& Federico, 2013a; Cortesogno, Gaggero, Lucchetti, \& Cabella, 2002) pointing to conditions of about $1,1 \mathrm{GPa}$ and $340 \pm 20{ }^{\circ} \mathrm{C}$ (Desmons, Compagnoni, \& Cortesogno, 1999 and references therein). The Montenotte Unit has been usually considered analogue to the Cravasco-Voltaggio Unit (e.g. Gelati \& Pasquarè, 1970; Vanossi et al., 1984) that crops out to the E of the Voltri Unit (Figure 1b).

Three deformational events have been described in the Montenotte Unit: two isoclinal transpositive folding phases with axial plane schistosity $\left(D_{1}\right.$ and $\left.D_{2}\right)$ and $\mathrm{D}_{3}$ characterized by open folding, with rare axial plane cleavages (Anfossi et al., 1984; Beccaluva et al., 1979). The contacts among lithologies are geometrically controlled by the composite foliation (CF) that includes the $\mathrm{D}_{1}$ and $\mathrm{D}_{2}$ related schistosity ( $\mathrm{F}_{1}$ and $\mathrm{F}_{2}$ after Anfossi et al., 1984; Capponi et al., 2013a); $\mathrm{D}_{1} / \mathrm{D}_{2}$ folds are coeval with blueschist facies metamorphism, whereas $\mathrm{D}_{3}$ folds are coeval with lowgrade metamorphism, with blastesis of albite + chlorite + epidote (Capponi et al., 2013a).

\subsection{The voltri unit}

The Voltri Unit crops out at the southeastern termination of the Ligurian Alps (Figure 1b), E-NE of the Montenotte Unit and is composed of metamorphic ophiolitic rocks with metasediments and slices of subcontinental lithospheric mantle (Chiesa et al., 1975; Rampone, Romairone, Abouchami, Piccardo, \& Hofmann, 2005). Meta-ophiolites correspond to serpentinite, metagabbro and metabasite, associated with calcschist, minor mica- and quartz-schist; mantle rocks encompass lherzolite and harzburgite with minor pyroxenite and dunite. The Voltri Unit attained eclogite facies conditions with blastesis of garnet + omphacite + rutile + Na-amphibole \pm phengite \pm clinozoisite in Fe-rich metagabbro (e.g. Bocchio, 1995; Ernst, 1976), that indicates peak metamorphic conditions of $\mathrm{P}=18-22 \mathrm{kbar}$ and $\mathrm{T}=500^{\circ} \mathrm{C}-600^{\circ} \mathrm{C}$ (e.g. Brouwer, Vissers, \& Lamb, 2002; Federico, Capponi, Crispini, \& Scambelluri, 2004; Liou, Zhang, Ernst, Liu, \& McLimans, 1998; Messiga, Piccardo, \& Ernst, 1983). Peak assemblages are later re-equilibrated by a greenschist facies metamorphic event.

In the Voltri Unit several deformational events have been recognized (Capponi \& Crispini, 2002, 2008; Malatesta et al., 2012; Vanossi et al., 1984): the oldest structures, related to the HP (High Pressure) metamorphic stage, are eclogite facies foliation and rootless hinges of isoclinal folds that have no continuity across outcrops. The most pervasive structures are tight to isoclinal transpositive $F_{1}$ and $F_{2}$ folds that are superposed and give rise to a composite fabric that controls contacts among different lithologies; they developed in metamorphic conditions ranging from Na-amphibole greenschist facies to greenschist facies s.s. (Capponi \& Crispini, 2002; Crispini \& Frezzotti, 1998). Later $D_{3}$ event encompasses $F_{3}$ folds and extensional shear 
zones; $\mathrm{F}_{3}$ folds are usually parallel folds, gentle to open in shape, in places associated to a roughly spaced cleavage. They developed in low greenschist facies metamorphic conditions. The $\mathrm{D}_{4}$ event (Capponi \& Crispini, 2002; Spagnolo, Crispini, \& Capponi, 2007) is characterized by non-metamorphic long wavelength asymmetric folds and by thrust faults that share the same top-to-the ENE sense of shear.

\subsection{The Tertiary Piedmont Basin (TPB)}

In the study area, the TPB is mainly composed of breccia, conglomerate and sandstone of continental to shallow marine environments (Molare Formation) that cover the metamorphic basement (e.g. Capponi et al., 2013a; Capponi, Crispini, \& Piazza, 2013b; Lorenz, 1968); hence the Montenotte and the Voltri units are the stratigraphic substratum of the TPB in this area.

\subsection{Relations among the units}

As concerns the structural relations between the units, in the past literature (Anfossi et al., 1984; Gelati \& Pasquarè, 1970) the Montenotte Unit has been described or interpreted as tectonically placed onto the Voltri Unit through sub-horizontal thrust surfaces. The TPB is in most cases transgressive over the metamorphic bedrock, but locally $\mathrm{D}_{4}$ deformations involve also the sedimentary cover, resulting in the tectonic emplacement of the metamorphic rocks onto the clastic sediments of the TPB.

\section{Geology of the mapped area}

\subsection{Voltri unit}

The Voltri tectono-metamorphic Unit consists of:

\subsubsection{Monte Tobbio peridotite (LHP)}

It consists of partially serpentinized peridotite mainly represented by lherzolite, with harzburgitic bodies, dunite lenses and bands of pyroxenite. They commonly grade into the serpentinite, where not in fault contact. The peridotite occurs in the northeastern part of the map, in a km-scale body and shows relic mantle texture, mainly a tectonite foliation.

4.1.2. Bric del Dente serpentinite (SNV)

It represents the predominant lithology of the Voltri Unit in the study area and consists of serpentinite and serpentine-schist, in places with textural relics of the original peridotite. The main mineralogic association consists of antigorite, magnetite, chlorite, olivine, diopside, tremolite, ankerite and Ti-clinohumite. Serpentinite is commonly characterized by a pervasive composite schistosity, multiple folding and shear bands.

\subsubsection{Colma metagabbro (MGV)}

It is mostly a leucocratic metagabbro, with relic eclogitic paragenesis (garnet, $\mathrm{Cr}$-mica, omphacite and glaucophane) and pervasive greenschist facies overprint (albite, tremolite, Mg-chlorite, epidote and minor white mica, titanite, talc, oxydes). It is present in $\mathrm{m}$ scale lenses inside the serpentinite, in the southern part of the map.

4.1.4. Rossiglione metabasite (MIV)

The metabasite (Prasiniti Auct.) occurs both as melanocratic and leucocratic facies, with layered or foliated textures. Metabasite derives from gabbro or basalt protoliths, but the original textures are commonly erased by metamorphism and deformation. Metabasite shows a pervasive greenschist facies recrystallization, locally with relic minerals related 
to the HP metamorphism. It is mainly made up of Ca-amphibole, chlorite, albite, epidote and minor Fe-Ti oxides, titanite, talc, biotite, calcite and white mica; locally relics of Na-amphibole and garnet (related to the HP metamorphism) have been detected.

4.1.5. Turchino calcschist (TUR)

The TUR formation includes micaschist, quartz-micaschist and carbonate schist, with mineralogic assemblages characterized by quartz, white mica, calcite, chlorite, biotite, pyrite, commonly re-equilibrated in greenschist facies conditions. Locally garnet, chloritoid and fengitic mica relics, related to the HP metamorphic stages, occur. A pervasive composite schistosity related to different deformational events characterizes all the outcrops of TUR.

The features observed in the study area thus support the description of the Voltri Unit arising from literature (see par. 3.2), namely that it represents a metamorphosed ophiolitic succession, characterized by a great abundance of serpentinite, which locally still shows primary contacts with gabbro bodies. The metasediments are interlayered with metabasite in places and represent the metamorphic equivalent of silicic sediments, limestones and pelites.

\subsection{Montenotte unit}

The Montenotte tectono-metamorphic Unit is made up of:

\subsubsection{Bric Autzè serpentinite (TIG)}

It is a massive chrysotile and antigorite bearing serpentinite with mineralogical and textural relics of the original peridotite, in places foliated or cataclastic.

4.2.2. Rocca Ghingherina metagabbro (MGH)

In the mapped area it is the predominant lithology and occurs as a km-scale NW-SE elongated body. It is a blueschist facies $\mathrm{Fe}$ - and Ti-oxyde-rich metagabbro, with heterogeneously distributed textural and structural features; it is medium to fine-grained with a massive (Figure 2a) to gneissic or listate texture (Figure 2b). Locally basaltic dykes and lenses of quartz-diorite and plagiogranite occur. In massive MGH, magmatic clinopyroxene, plagioclase and oxydes sites are pseudomorphosed by amphibole, epidote, chlorite and titanite (HT oceanic metamorphism). The alpine blueschist-facies assemblage consists of Na-amphibole, Na-Ca-clinopyroxene, lawsonite, pumpellyite, albite, titanite, chlorite, epidote. Late greenschist facies overprint occurs at places with actinolite and albite blastesis. At sites the MGH shows a penetrative foliation and shear bands; such structures are linked in places to the HT oceanic metamorphic event and in places to the blueschist metamorphic event; locally the HT foliation show topotactic replacement by HP assemblages.

4.2.3. Bric del Tamburo metabasalt (MBD)

MBD is a blueschist facies metabasalt consisting of albite, Na-amphibole, chlorite, epidote, lawsonite, pumpellyite, titanite. In most places it is foliated and relics of the basalt ophitic texture are rarely still detectable. In the study area it occurs in lenses associated with the MGH metagabbro.

4.2.4. Pian del Pino phylladic schist (FPI)

It is a grey-to-black phylladic schist, locally interlayered with limestone (Figure 2c) and commonly with quartz veins and veinlets. It is characterized by a composite schistosity defined by muscovite, clay minerals, quartz and minor graphite and carbonate. This foliation is the axial plane of isoclinal and intrafoliar folds, and is overprinted by a later crenulation cleavage, at places associated to a dissolution cleavage.

The features observed in the study area thus support the description of the Montenotte Unit arising from literature (see par. 3.1), namely that it represents a metamorphic ophiolitic 


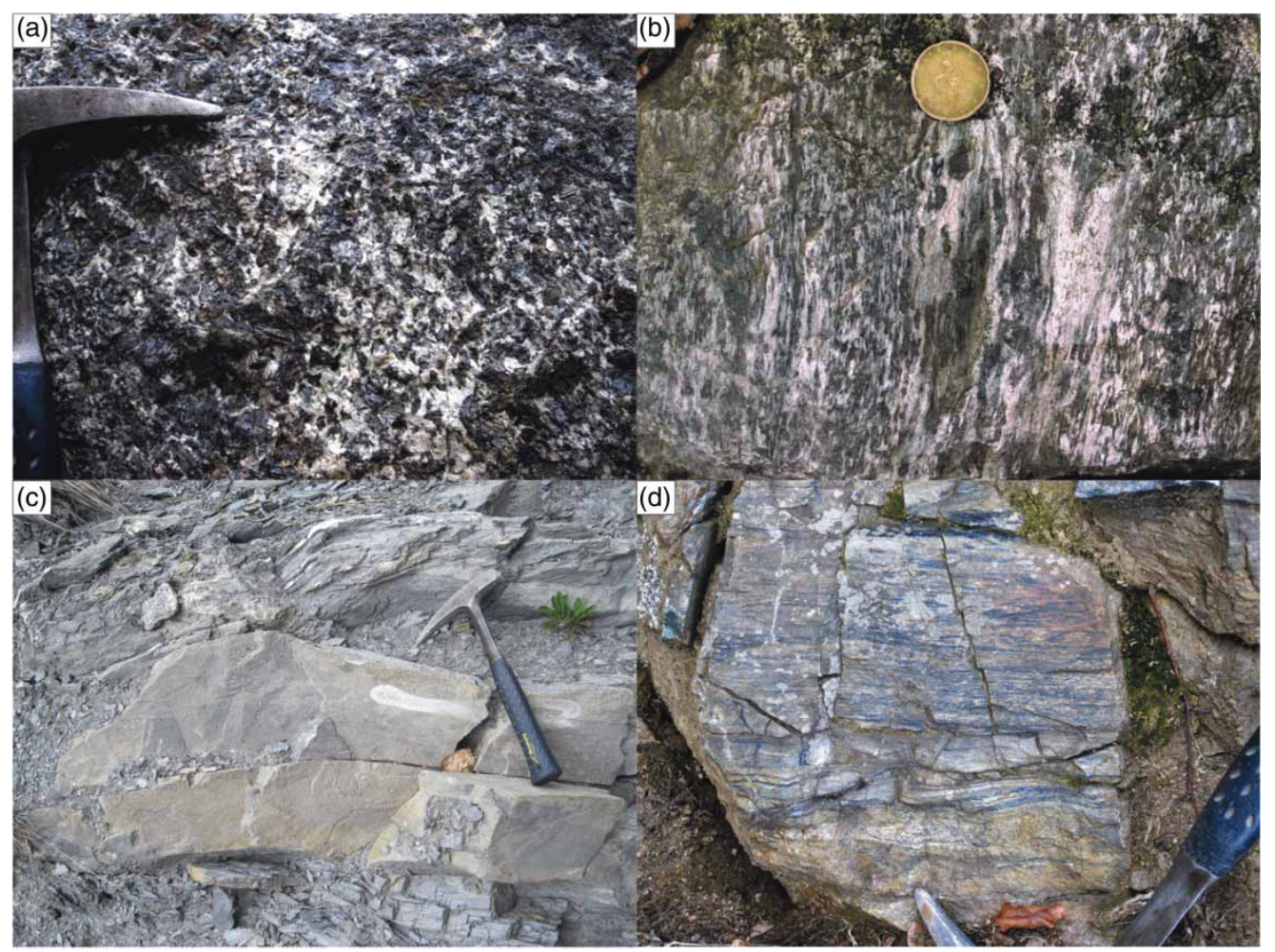

Figure 2. (a) Blueschist-facies metagabbro (MGH) with massive granular texture. (b) Pervasive blueschistfacies schistosity in metagabbro (MGH). (c) dm-thick limestone layers within phylladic schist (FPI). (d) Blueschist-facies mylonite at the contact between the Montenotte and Voltri units.

succession, with a particularly well-exposed gabbro section. Metasediments are the metamorphic equivalent of silicic sediments, limestones and pelites. Stratigraphic contacts between metabasalts and metasediments are rarely still observable.

\subsection{Tertiary piedmont basin}

\subsubsection{Molare Formation (MOR, MORm)}

In the mapped area the Molare Formation consists mainly of alluvial fan and fan delta deposits and minor transgressive shallow marine sediments (MORm, in the north-east of the map). The MOR sediments are heterometric, poorly sorted conglomerate with sandy matrix, locally interbedded with sandstone beds and fine-to-medium grained, poorly sorted sandstone (MORm), with silty matrix and calcareous cement, locally bioturbated. MOR contains abundant plant remains and brackish water mollusks of Oligocene age; MORm has an Upper Oligocene paleontologic content consisting of bivalves, worm tubes, frequent benthic foraminifers and rare planktonic foraminifers.

\section{Structural features}

The structural features of each unit up to their coupling, and then their common structural evolution, are described in the following. The attached structural sketch map and the relative crosssection show a summary of the main structural elements and our interpretation of the structural 
arrangement of the study area. We detected four deformation phases in each unit, with only the $\mathrm{D}_{3}$ and $\mathrm{D}_{4}$ common to both units (Table $1 \mathrm{a}$ and $1 \mathrm{~b}$ ).

\subsection{Structures of the Montenotte unit}

The Montenotte Unit records two deformational phases (that we call $\mathrm{D}_{1 \mathrm{mt}}$ and $\mathrm{D}_{2 \mathrm{mt}}$, Table 1a) characterized by tight to isoclinal folds, often strongly non-cylindrical, more recurrent in the philladic schists (Pian del Pino Schist). The superposition of the $\mathrm{D}_{1 \mathrm{mt}}$ and $\mathrm{D}_{2 \mathrm{mt}}$ folds gives rise to Type 3 interference patterns (Ramsay \& Huber, 1987), traceable at all levels from the microscopic to the map scale (see field photograph number 1 and the structural map). In most cases the $\mathrm{D}_{1 \mathrm{mt}}$ - and $\mathrm{D}_{2 \mathrm{mt}}$ - related schistosities are parallel, and they form a Composite Fabric $\left(\mathrm{CF}_{\mathrm{mt}}\right)$ that is the most evident foliation in the field. This $\mathrm{CF}_{\mathrm{mt}}$ shows a main NW-SE strike, but on the whole its attitudes are dispersed about a NE-SW girdle (Figure 3), that could be related to a successive phase of folding.

Because of the convergence in the geometry and style of the folds, the distinction between $D_{1 \mathrm{mt}}$ and $\mathrm{D}_{2 \mathrm{mt}}$ folds is not always possible; so we refer to them as $\mathrm{D}_{1 \mathrm{mt}} / \mathrm{D}_{2 \mathrm{mt}}$ (Figure 3 ). The axial planes of $\mathrm{D}_{1 \mathrm{mt}} / \mathrm{D}_{2 \mathrm{mt}}$ folds $\left(\mathrm{AP}_{1 \mathrm{mt} / 2 \mathrm{mt}}\right)$ show a main NW-SE strike and $\mathrm{SW}$ dip, but on the whole they are fully scattered, due to overprinting of the later $\mathrm{D}_{3}$ and $\mathrm{D}_{4}$ deformations. $\mathrm{D}_{1 \mathrm{mt}} /$ $\mathrm{D}_{2 \mathrm{mt}}$ folding event is syntectonic to the blueschist facies metamorphism as indicated by the mineralogic associations on axial plane foliation.

\subsection{Structures of the Voltri unit}

This unit is characterized by two deformational phases (that we call $\mathrm{D}_{1 \mathrm{vt}}$ and $\mathrm{D}_{2 \mathrm{vt}}$, Table $1 \mathrm{~b}$ ), with tight to isoclinal similar folds, often strongly non-cylindrical; their superposition produces Type 3 interference patterns (Ramsay \& Huber, 1987). Similarly to what described for the Montenotte Unit, the $D_{1 v t}$ - and $D_{2 v t}$ - related schistosities make a Composite Fabric, referred to as $C F_{v t}$; as the distinction between $\mathrm{D}_{1 \mathrm{vt}}$ and $\mathrm{D}_{2 \mathrm{vt}}$ folds is not always possible in the outcrops, we refer to them as $\mathrm{D}_{1 \mathrm{vt}} / \mathrm{D}_{2 \mathrm{vt}}$. In the study area, $\mathrm{CF}_{\mathrm{vt}}$ shows a dispersion about a NE-SW girdle (Figure 3), comparable to the $\mathrm{CF}_{\mathrm{mt}}$ dispersion, i.e., with the pole to the best-fit plane that is equivalent to a subhorizontal NW-SE trending fold axis that could be related to a subsequent phase of folding, possibly D3 (Figure 3). The $\mathrm{D}_{1 \mathrm{vt}} / \mathrm{D}_{2 \mathrm{vt}}$ folds have W-dipping axial planes and are syn-tectonic to the greenschist facies metamorphism, as indicated by a synkinematic assemblage of Ca-amphibole + chlorite + albite + epidote \pm Fe-Ti oxides \pm titanite \pm talc \pm biotite \pm calcite \pm white mica in metabasite. This agrees with what reported in literature (Capponi \&

Table 1. Main deformation phases and related metamorphic conditions: (a) in the Montenotte Unit; (b) in the Voltri Unit.

\begin{tabular}{cll}
\hline Deformation phase & \multicolumn{1}{c}{ Metamorphic conditions } & \multicolumn{1}{c}{ Fabric } \\
\hline (a) Montenotte unit & & \\
$\mathrm{D}_{1 \mathrm{mt}}$ & Blueschist & $\mathrm{CF}_{\mathrm{mt}}$ \\
$\mathrm{D}_{2 \mathrm{mt}}$ & Low greenschist & Axial plane cleavage \\
$\mathrm{D}_{3}$ & Non-metamorphic & None \\
$\mathrm{D}_{4}$ & & \\
(b) Voltri unit & (Na-amphibole greenschist)-greenschist & $\mathrm{CF}_{\mathrm{vt}}$ \\
$\mathrm{D}_{1 \mathrm{vt}}$ & Low greenschist & Axial plane Cleavage \\
$\mathrm{D}_{2 \mathrm{vt}}$ & Non-metamorphic & None \\
$\mathrm{D}_{3}$ & & \\
$\mathrm{D}_{4}$ & & \\
\hline
\end{tabular}




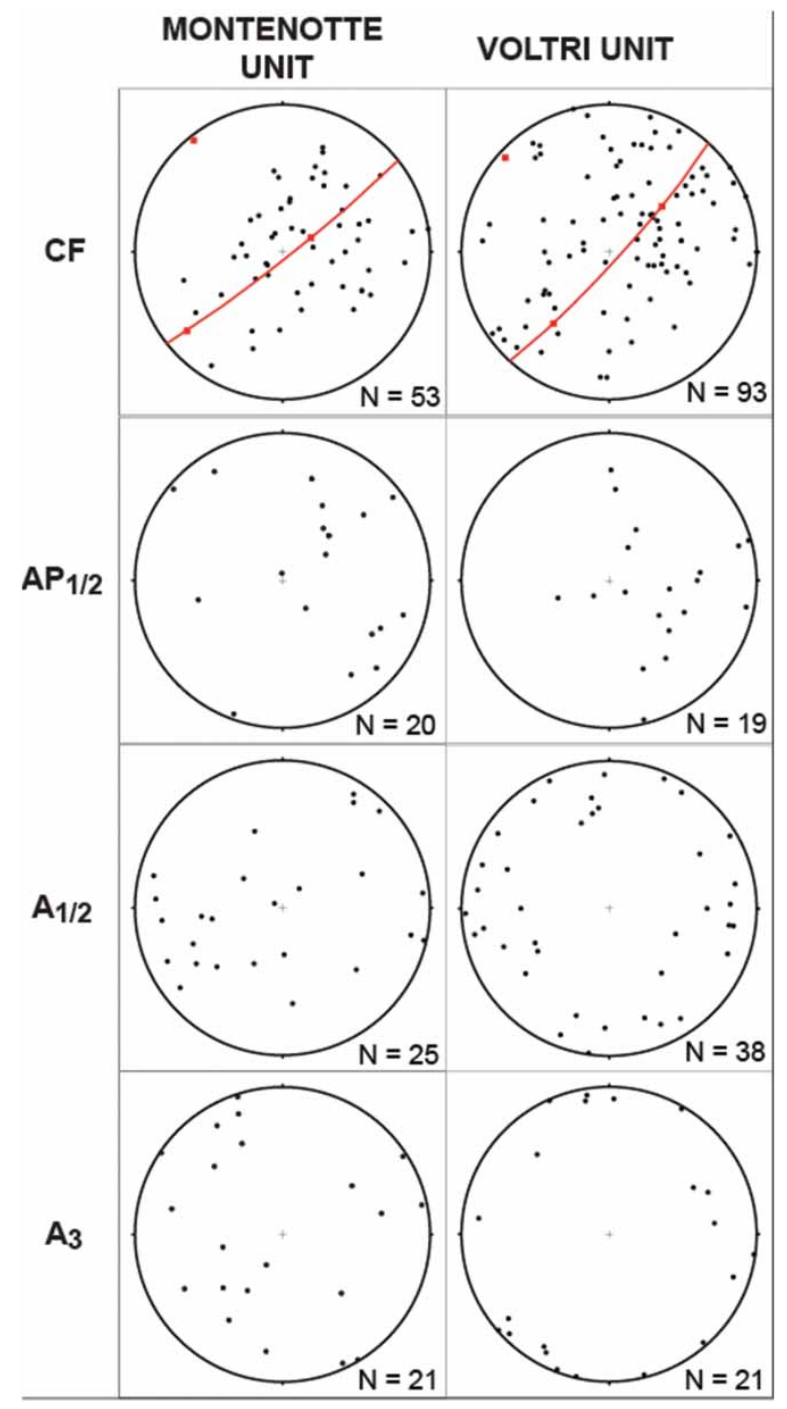

Figure 3. Stereoplots of main structural elements (equalarea projection, lower hemisphere) in the Montenotte and Voltri Units.

Crispini, 2002; Crispini \& Frezzotti, 1998), even if in this area the presence of Na-amphibole has not been observed. Relics of structures coeval with the eclogite facies metamorphism occur as intrafoliar rootless hinges of isoclinal folds.

\subsection{The contact between the Montenotte and the Voltri units}

In few outcrops of the study area the contact between the Montenotte and the Voltri units is characterized by the occurrence of a blueschist facies mylonite (Figure 2d). This mylonite is commonly fine grained and its main foliation is characterized by an assemblage of Na-amphibole + epidote + white mica + albite + chlorite + titanite + oxydes, with alternating levels rich in $\mathrm{Na}$-amphibole or in white mica + epidote. Moreover the mylonitic foliation is the axial plane 
of isoclinal similar folds (that we call $\mathrm{D}_{1 \mathrm{my}}$ folds). Both the mylonitic foliation and the folds are deformed by shear bands and foliation boudinage, that are syn-tectonic to the blueschist facies metamorphism. All these structures possibly developed in a regime of progressive deformation along a ductile shear zone. The strain partitioning and the concentration of deformation in limited volumes of rock triggered the development of a structural evolution that is peculiar of a shear zone and possibly independent from the adjoining rocks; as a result, $\mathrm{D}_{1 \mathrm{my}}$ folds have no direct correlation with the folds detected in the Montenotte Unit, albeit developed under the same blueschist facies metamorphic conditions.

The structural observations along the contact and the statistical analysis of the structural elements point to a first coupling between the Montenotte and Voltri units occurred during a tectonic event syn-metamorphic with the blueschist facies.

The Montenotte Unit, the Voltri Unit and their mylonitic contact are overprinted by a deformation phase $\left(D_{3}\right)$, characterized by open to gentle, sub-cylindrical folds, developed in low greenschist facies metamorphic conditions; $\mathrm{D}_{3}$ folds have main NE-SW and NW-SE trending axes (Figure 3; see cross-section of the structural sketch map).

The late stages of the structural evolution of the study area are characterized by large wavelength folds and thrust faults, with a top-to-the E-NE sense of tectonic transport. Locally the thrust surfaces place the Montenotte Unit onto the Voltri Unit; in the southeastern part of the mapped area, they place the metamorphic basement on the top of the Oligocene TPB sediments and locally cause the doubling of the sedimentary horizons in tectonic slices (see geological crosssection C-D).

These structures can be correlated with the $\mathrm{D}_{4}$ thrusts and folds, described in literature for adjoining areas (Capponi \& Giammarino, 1982; Capponi, Crispini, Silvestri, \& Vigo, 1999; Capponi, Crispini, Piazza, \& Amandola, 2001; Pasquarè, 1968) and are concordant with the ENE vergent backthrusting phase of the Ligurian Alps (Laubscher et al. 1992; Mosca, Polino, Rogledi, \& Rossi, 2010; Piana, Tallone, Cavagna, \& Conti, 2006). In a nearby area (Acqui Terme - Cassinelle) such structures have been constrained in age to the Aquitanian-Early Burdigalian (d'Atri, Piana, Tallone, Bodrato, \& Roz Gastaldi, 1997).

\section{Discussion}

The occurrence of the blueschist facies mylonite, albeit discontinuous, between the Montenotte and the Voltri units indicates that the two units were coupled during their exhumation path, under blueschist facies metamorphic conditions.

The age of this tectonic event can be roughly estimated considering the geochronological data available in literature. The existing estimations of the metamorphism age are related only to the Voltri Unit and they report a range between 49 to ca 43 Ma for the eclogitic stage (Federico, Capponi, Crispini, Scambelluri, \& Villa, 2005; Federico, Crispini, Scambelluri, \& Capponi, 2007; Hoogerduijn Strating, 1991; ), between ca 43 and ca 40 Ma for the blueschist facies metamorphism (Federico et al., 2007) and a range between ca 35 and ca 33 Ma for the greenschist facies metamorphism (Federico et al., 2005, 2007; Vignaroli et al., 2010). Hence the coupling of the two units has to be younger than the eclogite stage and older than the greenschist stage of the Voltri Unit metamorphism, i.e. between ca 43 and ca $35 \mathrm{Ma}$.

Afterwards, the Montenotte and the Voltri units were involved in the Aquitanian - Early Burdigalian E-NE vergent backthrusting event that characterizes the Ligurian Alps (d'Atri et al., 1997; Laubscher et al., 1992; Mosca et al., 2010; Piana et al., 2006), and as a consequence their early structural architecture was rearranged. 
In the eastern part of the Ligurian Alps, such brittle tectonics is pervasive and at present the mylonitic contact between the Montenotte and the Voltri units is in most places reworked by early Miocene E-NE vergent thrust faults.

If on one side the early mylonitic contact between the Montenotte and the Voltri units was severely reworked and disrupted by the superimposed brittle tectonics and hence hard to be detected, on the other side the early Miocene thrust faults are more evident; this is due also to the fact that such structures locally overturned the normal superposition between the metamorphic bedrock and the TPB sediments (placing the metamorphic onto the sedimentary rocks). It is hardly surprising, therefore, that the past literature described the superposition of the Montenotte onto the Voltri Unit as achieved by means of thrust faults, that, albeit common, is not the unique structural relation between the two units, and that conversely the early ductile coupling went unrecognized.

\section{Conclusions}

The new geological map is a substantial update compared to the previous geological maps and greatly improves the geological knowledge of the area. The Montenotte Unit and the Voltri Unit appear to have been coupled during their exhumation path, under blueschist facies metamorphic conditions. This is pointed out by the occurrence of a blueschist facies mylonite along the contact between the two units. This initial mylonitic contact was later reworked by the early Miocene brittle tectonics, that locally placed the Montenotte onto the Voltri Unit, through low-angle top-to-the E-NE thrust faults. The mapping of the top-to-the E-NE thrust faults that involves also the Molare Formation, allows the interpretation of the related tectonic event as the early Miocene 'backthrusting phase' of the Ligurian Alps (Laubscher et al., 1992; Mosca et al., 2010; Piana et al., 2006).

\section{Software}

The map has been drawn with ${ }^{\circledR}$ Adobe Illustrator CS4, coupled with ${ }^{\circledR}$ Avenza MaPublisher 8.3.3. to supply the vector drawing software with GIS capabilities. As usual, we first compiled a digital outcrop map that summarizes geological data not only in a graphical way (vector data), but also through a relational database containing both numerical, alphanumerical and boolean attributes. The different data hosted by the outcrop map encompass four types of GIS features:

- georeferenced raster images (Coordinate System Rome 1940 / Italy zone 1, Monte Mario /Italy 1);

- polygons (i.e. the outcrops);

- straight lines (i.e. tectonic lineaments seen through photointerpretation);

- points (i.e. sampling locations and attitude data).

Stereonet plots were produced using OSXStereonet 1.9 (Cardozo \& Allmendinger, 2013).

\section{Acknowledgements}

Thanks are due to Gian Mario Dabove, Michele Piazza, Eugenio Poggi and Andrea Vigo for field assistance during geological mapping. Base of data come from the geological mapping project 212 'Spigno Monferrato' quadrangle, funded by the Regione Liguria (Project Manager Gianna Gorziglia), that is gratefully acknowledged. Funding for this research was also provided by COFIN-MIUR 2010-2011 project entitled 'Birth and death of oceanic basins: geodynamic processes from rifting to continental collision in mediterranean and circum-mediterranean orogens'. 


\section{References}

Allasinaz, A., Gelati, R., Gnaccolini, M., Martinis, B., Orombelli, G., Pasquarè, G., \& Rossi, P. M. (1971). Note illustrative della Carta Geologica d'Italia alla scala 1/100000 - Foglio 82 Genova. Servizio Geologico d'Italia, 134 pp., Roma.

Anfossi, R., Colella, S., \& Messiga, B. (1984). Posizione strutturale e assetto litologico interno della falda di Montenotte, nella zona compresa tra i torrenti Letimbro e Sansobbia. Mem. Soc. Geol. It, 28, 371-384.

Beccaluva, L., Macciotta, G., Messiga, B., \& Piccardo, G. B. (1979). Petrology of the Blue-Schists metamorphic ophiolites of the Montenotte Nappe (Western Liguria-Italy). Ofioliti, 4, 239-268.

Bocchio, R. (1995). Chemical variations in clinopyroxenes and garnet from eclogites of the Vara Valley (Voltri Group), Italy. European Journal of Mineralogy, 7(10), 103-117.

Brouwer, F. M., Vissers, R. L. M., \& Lamb, W. M. (2002). Metamorphic history of eclogitic metagabbro blocks from a tectonic melange in the Voltri Massif, Ligurian Alps, Italy. Ofioliti, 27(1), 1-16.

Cabella, R., Cortesogno, L., Gaggero, L., \& Lucchetti, G. (1994). Clinopyroxenes through the blueschist facies metamorphism of the Liguria Alps: compositional variability and miscibility gaps. Atti Tic. Sc. Terra, Ser. Spec., 1, 55-63.

Capponi, G., \& Crispini, L. (2002). Structural and metamorphic signature of alpine tectonics in the Voltri Massif (Ligurian Alps, northwestern Italy). Ecl. Geol. Helv., 95, 31-42.

Capponi, G., \& Crispini, L. (2008). Note Illustrative del Foglio 213 - 230 "Genova" della Carta Geologica d'Italia alla scala 1:50.000. Apat - Regione Liguria, Selca, Firenze.

Capponi, G., Crispini, L., \& Federico, L. (with contributions by Cabella, R., Faccini, F., Ferraris, F., Firpo, M., Roccati, A., Marescotti, P., Piazza, M., \& Scambelluri, M. and collaboration by Dabove, G.M., Poggi, E., Torchio, S., Vigo, A. \& Vetuschi Zuccolini M.) (2013a). Note Illustrative al Foglio 212 "Spigno Monferrato" della Carta Geologica Regionale della Liguria. Retrieved from http://www. cartografia.regione.liguria.it/apriFoglia.asp?itemID $=30208 \&$ fogliaID $=1579 \&$ label $=$ Carta $\% 20$ Geologic a\%20Regionale $\% 20 \% 28$ CGR $\% 29 \% 20$ sc. $\% 201: 25000 \% 20$ riferita $\% 20$ al $\% 20$ Foglio $\% 20212 \% 20$ Spign o\%20Monferrato\%20-\%20sc.\%201:50000

Capponi, G., Crispini, L., \& Piazza, M. (with collaboration of Dabove G., Faccini F., Federico L., Ferraris F., Firpo M., Poggi E., Roccati A., Torchio S., Vigo A.) (2013b). Foglio 212.3 "Sassello", scala 1/25'000, Regione Liguria. Retrieved from http://www.regione.liguria.it/opendata/dati-cartografici/item/37914cartageologica-regionale-cgr-sc-125000-riferita-al-foglio-212-spigno-monferrato-sc-150000.html

Capponi, G., Crispini, L., Piazza, M., \& Amandola, L. (2001). Field constraints to the Mid-Tertiary kinematics of the Ligurian Alps. Ofioliti, 26(2b), 409-416.

Capponi, G., Crispini, L., Silvestri, R., \& Vigo, E. (1999). The role of Early Miocene thrust tectonics in the structural arrangement of the Voltri Group (Ligurian Alps, Italy): evidence from the Bandita area. Ofioliti, 24(1), 13-19.

Capponi, G., \& Giammarino, S. (1982). L'affioramento oligocenico di Rio Siria (Bacino di Santa Giustina, prov. Di Savona) nel quadro dei movimenti tardivi della Falda di Montenotte. Atti Soc. tosc. Di Sc. Nat., 89, 101-114.

Cardozo, N., \& Allmendinger, R. W. (2013). Spherical projections with OSXStereonet. Computers \& Geosciences, 51(0), 193-205. doi:10.1016/j.cageo.2012.07.021

Chiesa, S., Cortesogno, L., Forcella, F., Galli, M., Messiga, B., Pasquarè, G., ... Rossi, P. M. (1975). Assetto strutturale ed interpretazione geodinamica del Gruppo di Voltri. Boll. Soc. Geol. Ital., 94(3), 555-582.

Cortesogno, L., Gaggero, L., Lucchetti, G., \& Cabella, R. (2002). Compositional variability and miscibility gap in Na-Ca clinopyroxenes through high pressure metamorphism. Periodico di Mineralogia, 71(1), $1-25$.

Crispini, L. \& Frezzotti, M. L. (1998). Fluid inclusion evidence for progressive folding during decompression in metasediments of the Voltri Group (Western Alps, Italy). Journal of Structural Geology, 20(12), $1733-1746$.

d'Atri, A., Piana, F., Tallone, S., Bodrato, G., \& Roz Gastaldi, M. (1997). Tettonica Oligo-Miocenica nell'alto Monferrato (Bacino Terziario Piemontese) e nel settore nord-occidentale del Gruppo di Voltri (Acqui Terme - Cassinelle, AL). Atti Tic. Sc. Terra, (Serie speciale), 5, 85-100.

Desmons, J., Compagnoni, R., \& Cortesogno, L. (1999). Alpine metamorphism of the Western Alps: II. High P/T and related pre-greenschist metamorphism. Schweiz. Mineral. Petrogr. Mitt., 79, 111-134.

Ernst, W. G. (1976). Mineral chemistry of eclogites and related rocks from the Voltri Group, Western Liguria, Italy. Schweiz. Mineral. Petrogr. Mitt., 56, 293-343.

Federico, L., Capponi, G., Crispini, L., \& Scambelluri, M. (2004). Exhumation of alpine high pressure rocks: insights from petrology of eclogite clasts in the Tertiary Piedmontese basin (Ligurian Alps, Italy). Lithos, 74(1-2), 21-40. 
Federico, L., Capponi, G., Crispini, L., Scambelluri, M., \& Villa, I. M. (2005). 39Ar/40Ar dating of highpressure rocks from the Ligurian Alps: evidence for a continuous subduction - exhumation cycle. Earth and Planetary Science Letters, 240, 668-680.

Federico, L., Crispini, L., Scambelluri, M., \& Capponi, G. (2007). Different PT paths recorded in a tectonic melange (Voltri Massif, NW Italy): implications for the exhumation of HP rocks. Geodinamica Acta, 20, $3-19$.

Francani, V., Gelati, R., Martinis, B., Orombelli, G., Pasquarè, G., Rossi, P. M., \& Sfondrini, G. (1971). Note Illustrative della Carta Geologica d'Italia alla scala 1:100.000. Foglio 81 (Ceva). Nuova Tecnica Grafica, 100 pp, Roma.

Gelati, R., Gnaccolini, M. (1988). Sequenze deposizionali in un bacino episuturale, nella zona di raccordo tra Alpi ed Appennino settentrionale. Atti Tic. Sc. Terra, 31, 340-350.

Gelati, R., Gnaccolini, M. (1998). Synsedimentary tectonics and sedimentation in the Tertiary Piedmont Basin, Northwestern Italy. Riv. Ital. Paleont. Strat., 104, 193-214.

Gelati, R., \& Pasquaré, G. (1970). Interpretazione geologica del limite Alpi - Appennini in Liguria. Riv. Ital. Paleont. Strat., 76(4), 513-578.

Hoogerduijn Strating, E. H. (1991). Folding of litosphere in the Piemonte-Ligurian ocean. Geol. Mijnbouw, $69,31-41$.

Laubscher, H. P. (1971). The large - scale kinematics of the Western Alps and the Northern Apennines and its palinspastic implications. American Journal of Science, 271, 193-226.

Laubscher, H., Biella, G. C., Cassinis, R., Gelati, R., Lozej, A., Scarascia, S. \& Tabacco, I. (1992). The collisional knot in Liguria. Geologische Rundschau, 81(2), 275-289.

Liou, J. G., Zhang, R., Ernst, W. G., Liu, J., \& McLimans, R. (1998). Mineral parageneses in the Piampaludo eclogitic body, Gruppo di Voltri, Western Ligurian Alps. Schweiz. Mineral. Petrogr. Mitt., 78, 317-335.

Lorenz, C. (1968). Contribution a l'étude stratigraphique de l'oligocene e du miocene inferieur des confins ligure-piemontais (Italie). Atti dell'Istituto di Geologia dell'Università di Genova, 6(2), 273-889.

Malatesta, C., Crispini, L., Federico, L., Capponi, G., \& Scambelluri, M. (2012). The exhumation of high pressure ophiolites (Voltri Massif, Western Alps): Insights from structural and petrologic data on metagabbro bodies. Tectonophysics, 568/569, 102-123. doi:10.1016/j.tecto.2011.08.024

Messiga, B., \& Piccardo, G. B. (1980). Metamorphic Ophiolites of the Voltri Massif and the Montenotte Nappe, Western Liguria. Field Excursion Guide Book. VI Ophiolite Field Conference, Gruppo di lavoro sulle ofioliti mediterranee, Firenze 1980, 123-153.

Messiga, B., Piccardo, G. B., \& Ernst, W. G. (1983). High pressure Eo-Alpine parageneses developed in magnesian metagabbros, Gruppo di Voltri, Western Liguria, Italy. Contributions to Mineralogy and Petrology, 83, 1-15.

Mosca, P., Polino, R., Rogledi, S., \& Rossi, M. (2010). New data for the kinematic interpretation of the Alps Apennines junction (Northwestern Italy). International Journal of Earth Sciences, 99, 833-849.

Mutti, E., Papani, L., Di Biase, D., Davoli, G., Mora, S., Segadelli, S., Tinterri, R. (1995). Il Bacino Terziario Epimesoalpino e le sue implicazioni sui rapporti tra Alpi e Appennino. Memorie di Scienze Geologiche, $47,217-244$.

Pasquarè, G. (1968). La "Serie di Montenotte": un elemento alloctono sovrapposto al bacino oligocenico di S. Giustina (Alpi Liguri). Riv. Ital. Paleont. Strat., 74, 1257-1274.

Piana, F., Tallone, S., Cavagna, S., \& Conti, A. (2006). Thrusting and faulting in metamorphic and sedimentary units of Ligurian Alps: an example of integrated field work and geochemical analyses. International Journal of Earth Sciences (Geol Rundsch), 95, 413-430. doi:10.1007/s00531-005-0040-z

Polino, R., Dal Piaz, G. V., \& Gosso, G. (1990). Tectonic erosion at the Adria margin and accretionary process for the Cretaceous orogeny in the Alps. In F. Roure, P. Heitzmann, R. Polino (Eds.), Deep structure of the Alps. Mém. Soc. géol. Fr., Paris, 156; Mém. Soc. géol. suisse, Zurich, 1; Vol. spec. Soc. Geol. It., Roma, 1, 345-367.

Rampone, E., Romairone, A., Abouchami, W., Piccardo, G. B., \& Hofmann, A. W. (2005). Chronology, Petrology and Isotope Geochemistry of the Erro-Tobbio Peridotites (Ligurian Alps, Italy): Records of Late Palaeozoic Lithospheric Extension. Journal of Petrology, 46(4), 799-827. doi:10.1093/ petrology/egi001

Ramsay, J. G., \& Huber, M. I. (1987). The techniques of modern structural Geology. Volume 2: folds and fractures. London: Academic Press.

Spagnolo, C., Crispini, L., \& Capponi, G. (2007). Late structural evolution in an accretionary wedge: insights from the Voltri Massif (Ligurian Alps, Italy). Geodinamica Acta 20(1/2), 21-35.

Spalla, M. I., Zucali, M., Di Paola, S., \& Gosso, G. (2005). A critical assessment of the tectono - thermal memory of rocks and definition of tectono - metamorphic units: evidence from fabric and degree of 
metamorphic transformations. In: Gapais, D., Brun, J. P. \& Cobbold, P. R. (Eds.), Deformation mechanisms, Rheology and tectonics: from minerals to the lithosphere. Geological Society, London, Special Publications, 243, 227-247.

Vanossi, M., Cortesogno, L., Galbiati, B., Messiga, B., Piccardo, G., \& Vannucci, R. (1984). Geologia delle Alpi Liguri: dati, problemi, ipotesi. Mem. Soc. Geol. It., 28, 5-75.

Vignaroli, G., Rossetti, F., Rubatto, D., Theye, T., Lisker, F., \& Phillips, D. (2010). Pressure-temperaturedeformation-time (PTdt) exhumation history of the Voltri Massif HP complex, Ligurian Alps, Italy. Tectonics, 29(6), TC6009. doi:10.1029/2009TC002621 